\title{
Kajian In Vitro Kecernaan Fraksi Serat Hijauan Tropis pada Media Cairan Rumen Kambing
}

\author{
Marselinus Hambakodu, Alexander Kaka, Yessy Tamu Ina \\ Prodi Peternakan, Fakultas Sains dan Teknologi, Universitas Kristen Wira Wacana Sumba \\ Jl. R. Suprapto No. 35, Waingapu, Prailiu, Kabupaten Sumba Timur NTT \\ Email korespondensi: mhambakodu91@gmail.com
}

(Diterima: 09-10-2019; Disetujui:14-12-2019)

\begin{abstract}
ABSTRAK
Penelitian ini bertujuan untuk mengevaluasi kecernaan NDF, kecernaan ADF dan kecernaan hemiselulosa pada hijauan pakan tropis secara in vitro. Materi yang digunakan dalam penelitian ini adalah 8 jenis pakan hijauan tropis dan cairan rumen kambing PE berfistula yang diberi pakan dengan kandungan PK $12 \%$ dan TDN $62 \%$. Rancangan percobaan yang digunakan adalah rancangan acak lengkap 8 perlakuan pakan dan 3 ulangan. Perlakuan terdiri dari $\mathrm{P} 1=$ turi (Sesbania grandiflora $), \mathrm{P} 2=$ nangka (Artocarpus heterophyllus), $\mathrm{P} 3=$ pisang (Musa acuminate), $\mathrm{P} 4=\operatorname{mangga}($ Mangifera indica L.), P5 = gamal (Gliricidia sepium), P6 = mahoni (Swietenia mahagoni (L.) Jacq.), P7 = kaliandra (Calliandra calothyrsus) dan P8 = lamtoro (Leucaena leucocephala). Data dianalisis menggunakan ANOVA taraf 5\%, dan dilanjutkan dengan uji Duncan. Hasil penelitian menunjukkan bahwa kecernaan $\mathrm{NDF}$, kecernaan $\mathrm{ADF}$, dan kecernaan hemiselulosa berbeda nyata $(\mathrm{P}<0,05)$. Hijauan pakan tropis lamtoro, kaliadra dan gamal memiliki kecernaan NDF, kecernaan ADF lebih tinggi dibandingkan turi, nangka, pisang, mangga, dan mahoni, namun kecernaan hemiselulosa kaliandra, manga dan lamtoro tertinggi. Kesimpulan, hijauan Leucaena leucocephala, Calliandra calothyrsus, dan Gliricidia sepium memiliki kecernaan NDF tertinggi $(70,34 \% ; 66,26 \%$ dan 62,29\%), dan kecernaan ADF tertinggi (53,79\%; 48,08\%; dan 58,91\%), namun kecernaan hemiselulosa tertinggi adalah Calliandra calothyrsus, Mangifera indica L, dan Leucaena leucocephala (18,18\%; 17,80\% dan 16,55\%).
\end{abstract}

Kata kunci: in vitro, hijauan tropis, kecernaan, serat

\begin{abstract}
This research was conducted to evaluate neutral detergent fiber digestibility, acid detergent fiber digestibility, and hemicellulose digestibility on tropical browse plants in vitro. The materials used in this research were 8 types of tropical forages and rumen fluid from Etawa Crossbreed goat fistulated with CP $12 \%$ and $62 \%$ TDN. The experimental design used was the completely randomized design of 8 feed treatments and 3 replications. Treatments consisted of $\mathrm{P} 1=$ Sesbania grandiflora, $\mathrm{P} 2=$ Artocarpus heterophyllus, $\mathrm{P} 3=$ Musa acuminata, $\mathrm{P} 4=$ Mangifera indica L., $\mathrm{P} 5=$ Gliricidia sepium, P6 = Swietenia mahagoni (L.) Jacq, P7 = Calliandra calothyrsus, and P8 = Leucaena leucocephala . Data were analyzed using ANOVA 5\%, and continued by Duncan test. The results of the study showed that neutral detergent fiber digestibility, acid detergent fiber digestibility, hemicellulose digestibility were significantly $(\mathrm{P}<0.05)$. Tropical forages of Leucaena leucocephala and Gliricidia sepium were highest neutral detergent fiber digestibility $(70,34 \%$ and $62,29 \%)$, and highest acid detergent fiber digestibility $(57,14 \%$ and $58,91 \%)$, with hemicellulose digestibility $(64,10 \%$ and $65,00 \%)$.
\end{abstract}

Keywords: digestibility, fiber, tropical browse plants, in vitro.

\section{PENDAHULUAN}

Keberhasilan usaha peternakan salah satunya dipengaruhi oleh faktor pakan, baik secara kualitas, kuantitas dan kontinuitas. Umumnya peternak memberikan pakan ternak berupa hijauan baik dari tanaman rumput (graminae) maupun kacangkacangan (leguminosa) dan non leguminosa (Hadi et al., 2011). Pakan hijuan tropis di Indonesia cukup 
banyak serta beberapa hijauan tersebut memiliki kandungan nutrisi yang cukup tinggi. Kualitas nutrisi yang tinggi ini belum diikuti oleh pemanfaatannya yang optimum, hal ini disebabkan adanya kadar serat kasar dan anti nutrisi yang cukup tinggi pada hijauan tersebut. Serat kasar ini dapat dimanfaatkan sebagai sumber energi bagi ternak kambing melalui proses fermentasi pakan didalam rumen. Hijauan legum pohon merupakan komoditas pakan ternak yang banyak tersedia dan tidak bergantung pada musim di negara tropis seperti Indonesia (Ikhwanti et al., 2018).

Pakan hijauan tropis yang sering digunakan sebagai pakan ternak di Indonesia adalah turi (Sesbania grandiflora), nangka (Artocarpus heterophyllus), pisang (Musa acuminata), mangga (Mangifera indica L.), gamal (Gliricidia sepium), mahoni (Swietenia mahagoni (L.) Jacq.), kaliandra (Calliandra calothyrsus), dan lamtoro (Leucaena leucocephala). Jenis pakan hijauan tropis memiliki kualitas nutrisi yang berbeda-beda. Pakan hijauan tropis pada umumnya mengandung serat kasar tinggi dan protein rendah. Tingginya kandungan serat akan berpengaruh pada kecernaan dalam rumen dan pemanfaatan energi pakan kurang efisien karena tingginya produksi metan dalam rumen (Asikin et al., 2018; Jayanegara et al., 2018).

Karakteristik serat NDF antar hijauan pakan berbeda, demikian juga setiap bagian dari hijauan, mempunyai kandungan serat dan nilai nutrien yang berbeda pula. Kandungan nutrien serat pakan komplit yang sama menyebabkan kecernaan NDF sama didalam rumen (Hambakodu dan Ina, 2019; Hambakodu et al., 2019). Kualitas nutrisi yang berbeda-beda tersebut dapat dicerminkan melalui kecernaan nutrien didalam rumen, salah satunya kecernaan serat (kecernaan NDF, ADF, dan hemiselulosa). Evaluasi nutrien yang berbeda dari hijauan tropis terhadap nilai kecernaan serat masih terbatas. Berdasarkan permasalan diatas, maka perlu kajian atau evaluasi berbagai bahan pakan hijauan tropis terhadap nilai kecernaan serat didalam rumen ternak kambing secara in vitro.

\section{MATERI DAN METODE}

Materi yang digunakan adalah pakan hijauan tropis berupa daun pisang, daun manga, daun lamtoro, daun turi, daun nangka, daun kaliandra, daun mahoni, dan daun gamal serta 1 ekor kambing Peranakan Etawa (PE) berfistula yang diberi pakan standar dengan kandungan PK $12 \%$; TDN $62 \%$; dan NDF 55,10 \% (Tabel 1). Bahan yang digunakan yaitu cairan rumen kambing PE, larutan McDougall, larutan pepsin $\mathrm{HCl} 0,2 \%$, larutan NDS (neutral detergent solution), larutan ADS (acid detergent solution), aquades, $\mathrm{Na}_{2} \mathrm{SO}_{3}$, larutan alkohol. Alat yang digunakan yaitu timbangan digital, disk mill ukuran $2 \mathrm{~mm}$, timbangan analitik merk Ohaus, kertas saring, krusibel, waterbath, sentrifuse, thermometer, termos, kain kasa, tabung fermentor, tabung reaksi, eksikator, oven, dan tanur.

Percobaan terdiri dari 8 perlakuan pakan hijauan tropis dan masing-masing diulang sebanyak 3 kali, dirancang dengan mengguna-kan metode eksperimental rancangan acak lengkap (RAL) sebagai berikut $\mathrm{P} 1=$ turi (Sesbania grandiflora), $\mathrm{P} 2$ = nangka (Artocarpus heterophyllus), $\mathrm{P} 3=$ Pisang (Musa acuminata), $\mathrm{P} 4=$ Mangga (Mangifera indica L.), P5 = Gamal (Gliricidia sepium), P6 = mahoni (Swietenia mahagoni (L.) Jacq.), P7 = kaliandra (Calliandra calothyrsus), P8 = lamtoro (Leucaena leucocephala). Variabel yang diukur meliputi kecernaan neutral detergent fiber (NDF), kecernaan acid detergent fiber (ADF), dan kecernaan hemiselulosa.

Tabel 1. Komposisi dan kandungan nutrien pakan standar kambing PE

\begin{tabular}{lc}
\hline Bahan Pakan (\%BK) & Komposisi \\
\hline Rumput gajah & 50 \\
Pollard & 12 \\
Bekatul & 11 \\
Onggok & 13 \\
Bungkil kedelai & 6 \\
Bungkil kelapa sawit & 8 \\
Kandungan Nutrien (\%) & \\
Protein Kasar (PK) & 12,02 \\
Total Digestible Nutrient $(T D N)^{*}$ & 62,34 \\
Neutral Detergent Fiber $(N D F)$ & 55,10 \\
\hline Keterangan: TDN* dihitung berdasarkan perhitungan Hartadi et al. $(2017)$
\end{tabular}


Analisis proksimat (AOAC, 1990) untuk mengetahui kandungan $\mathrm{BK}, \mathrm{BO}, \mathrm{PK}, \mathrm{LK}$, SK dari sampel. Analisis serat (Van Soest, 1977) untuk mengetahui kandungan NDF, ADF, selulosa, lignin. Perhitungan kecernaan selama 2 x 48 jam. Setelah masa inkubasi 2 x 48 jam, residu disaring dengan krusibel Gooch, kemudian dianalisis kandungan NDF, ADF dan Hemiselulosa. Rumus untuk perhitungan kecernaan menurut Tilley \& Terry (1963) sebagai berikut:

$$
\begin{gathered}
\% \mathrm{KcNDF}=\frac{\text { NDF sampel }(\mathrm{g})-((\mathrm{NDF} \text { residu }(\mathrm{g})-\mathrm{NDF} \text { blanko }(\mathrm{g})}{\text { NDF sampel }(\mathrm{g})} \times 100 \% \\
\% \mathrm{KcADF}=\frac{\text { ADF sampel }(\mathrm{g})-\text { ADF residu }(\mathrm{g})-\text { ADF blanko }(\mathrm{g})}{\text { ADF sampel }(\mathrm{g})} \times 100 \%
\end{gathered}
$$

$\%$ Kecernaan Hemiselulosa $=\%$ Kecernaan NDF - \% Kecernaan ADF

Data dianalisis menggunakan analisis ragam pada taraf kepercayaan 5\%, dan dilanjutkan uji beda antar perlakuan menggunakan Duncan's multiple range test.

\section{HASIL DAN PEMBAHASAN}

\section{Gambaran Nutrien Pakan Hijauan Tropis}

Komposisi nutrien analisis proksimat dan analisis serat dari masing-masing bahan pakan ditampilkan pada Tabel 1. Berdasarkan uji proksimat pakan hijauan tropis lamtoro (Leucaena leucocephala), kaliandara (Calliandra calothyrsus), dan gamal (Gliricidia sepium) memiliki kandungan protein kasar tertinggi $32,04 \%$; $25,96 \%$; dan $25,39 \%$ yang cukup tinggi dibanding yang lainnya. Lamtoro merupakan hijauan tropis yang unggul sebagai sumber protein dengan kandungan PK 23,20\% yang cocok digunakan sebagai pakan ruminansia (Ahmed et al., 2018). Kandungan fraksi serat dari pakan lamtoro, kaliandra, dan gamal mengandung NDF secara berturut-turut $(33,44 \% ; 51,19 \%$; dan $37,88 \%)$, ADF $(23,05 \%$; $38,74 \%$; dan $25,02 \%)$, selulosa $(18,05 \%$; $17,11 \%$; dan $17,33 \%)$, serta lignin $(4,97 \%$; $21,63 \% ; 7,69 \%)$. Kandungan nutrien dari bahan pakan turut menentukan nilai kecernaan serat didalam rumen. Kandungan serat seperti NDF pakan yang sama akan menghasilkan nilai kecernaan serat yang sama didalam rumen (Hambakodu et al., 2019).

Kandungan nutrien dari ketiga pakan hijuan tropis tersebut memiliki potensi nutrisi yaitu protein kasar tinggi dan kandungan lignin yang redah dibandingkan pakan hijauan lainnya. Potensi ini sangat menguntungkan ternak ruminansia saat pakan tersebut dicerna didalam rumen.

Tabel 2. Kandungan nutrien pakan hijauan tropis

\begin{tabular}{lcccccccc}
\hline \multicolumn{1}{c}{$\begin{array}{c}\text { Kandungan } \\
\text { Nutrien }\end{array}$} & \multicolumn{7}{c}{ Bahan Pakan Hijauan } \\
\cline { 2 - 9 } & P1 & P2 & P3 & P4 & P5 & P6 & P7 & P8 \\
\hline BK & 91,17 & 90,75 & 91,72 & 92,27 & 92,03 & 90,03 & 91,82 & 91,65 \\
BO & 96,26 & 94,04 & 93,92 & 93,74 & 96,12 & 96,27 & 96,28 & 96,13 \\
PK & 27,64 & 15,53 & 15,52 & 8,99 & 25,39 & 12,72 & 25,96 & 32,04 \\
LK & 3,85 & 2,35 & 4,81 & 1,53 & 3,96 & 2,06 & 0,82 & 2,66 \\
BETN & 8,73 & 21,18 & 18,86 & 34,77 & 22,43 & 46,37 & 35,13 & 40,98 \\
SK & 56,04 & 54,98 & 54,73 & 48,45 & 44,34 & 35,12 & 34,37 & 20,45 \\
NDF & 45,35 & 29,75 & 46,89 & 47,74 & 37,88 & 39,24 & 51,19 & 33,44 \\
ADF & 29,28 & 19,23 & 31,52 & 44,06 & 25,02 & 31,31 & 38,74 & 23,05 \\
Selulosa & 9,21 & 2,33 & 4,34 & 14,62 & 17,33 & 12,86 & 17,11 & 18,05 \\
Lignin & 20,07 & 16,93 & 27,18 & 29,44 & 7,69 & 18,45 & 21,63 & 4,97 \\
Abu & 3,74 & 5,96 & 6,08 & 6,26 & 3,88 & 3,73 & 3,72 & 3,87 \\
\hline
\end{tabular}

Keterangan: $\mathrm{BK}=$ bahan kering, $\mathrm{BO}=$ bahan organik, $\mathrm{PK}=$ protein kasar, $\mathrm{LK}=$ lemak kasar, $\mathrm{SK}=$ serat kasar, $\mathrm{NDF}=$ neutral detergent fiber, $\mathrm{ADF}=$ acid detergent fiber $. \mathrm{P} 1=$ Sesbania grandiflora, $\mathrm{P} 2=$ Artocarpus heterophyllus, $\mathrm{P} 3=$ Musa acuminata, $\mathrm{P} 4=$ Mangifera indica L., $\mathrm{P} 5=$ Gliricidia sepium, P6 = Swietenia mahagoni (L.) Jacq., P7 = Calliandra calothyrsus, dan P8 = Leucaena leucocephala. 
Kandungan lignin yang rendah mikroba rumen dapat dengan mudah mencerna pakan, sedangkan protein kasar yang tinggi bagi mikroba rumen memanfaatkan nitrogen untuk kebutuhan sintesis protein mikroba. Kandungan protein kasar yang tinggi pada hijauan berpotensi untuk dimanfaatkan sebagai sumber suplemen protein dalam pakan ternak ruminansia (Marhaeniyanto \& Susanti, 2018). Lignin yang terdapat dalam dinding sel tanaman merupakan faktor pembatas kecernaan didalam rumen. Lignin yang tinggi dalam pakan menyebabkan nilai kecernaan rendah didalam rumen. Lignin tidak dapat dicerna oleh mikroba didalam rumen, bahkan dapat mengganggu kecernaan, sedangkan serat kasar memiliki fraksi selain lignin juga mengandung selulosa dan hemiselulosa yang dapat dicerna oleh mikroba rumen (Hernaman et al., 2017).

\section{Kecernaan NDF}

Kecernaan neutral detergent fiber (NDF) merupakan gambaran nutrien serat NDF yang dicerna oleh mikroba didalam rumen (Hambakodu et al., 2019). Analisis ragam menujukkan bahwa perlakuan pakan hijauan tropis berbeda nyata $(\mathrm{P}<0,05)$ terhadap kecernaan NDF. Kecernaan NDF yang berbeda dipengaruhi oleh kandungan nutrien pakan hijauan tropis saat difermentasi didalam rumen. Kandungan nutrien selulosa tertinggi Leucaena leucocephala, Calliandra calothyrsus dan Gliricidia sepium $(18,05 \% ; 17,11 \%$ dan $17,33 \%)$ dan lignin rendah $(4,97 \% ; 21,63 \%$ dan $7,69 \%$ ) sehingga menyebabkan kecernaan NDF tinggi. Kandungan lignin yang rendah serta diikuti dengan kanduungan selulosa yang tinggi pada pakan tersebut memudahkan bakteri rumen mencerna pakan secara efektif didalam rumen. Faktor yang dapat mempengaruhi kecernaan adalah komposisi kimiawi dari pakan perlakuan dan senyawa metabolit sekunder seperti tanin dari legum (Priyanto et al., 2017). Penggunaan daun tanaman dalam pakan konsentrat ruminansia menghasilkan fermentabilitas yang normal dan kecernaan yang baik (Marhaeniyanto dan Susanti, 2018). Penggunaan daun tanaman legum seperti lamtoro, kaliandra dan gamal bagi ruminansia masih bisa ditoleransi dan dicerna oleh mikroba rumen dengan baik.

Uji wilayah Duncan menunjukkan bahwa perlakuan pakan lamtoro (Leucaena leucocephala) dan kaliandra (Calliandra calothyrsus) berbeda nyata dengan perlakuan pakan gamal (Gliricidia sepium), nangka (Artocarpus heterophyllus), mahoni (Swietenia mahagoni (L.) Jacq.), mangga (Mangifera indica L.), pisang (Musa acuminata), dan turi (Sesbania grandiflora). Hasil penelitian menunjukkan kecernaan NDF tertinggi lamtoro, kaliandra dan gamal, sedangkan kecernaan NDF terendah daun turi, daun pisang, dan daun mangga. Tinggi rendahnya kecernaan NDF dipengaruhi oleh kandungan lignin dan selulosa dari pakan hijauan. Tingkat kecernaan pada pakan dapat digunakan untuk mengukur indikator kualitas pakan. Kandungan selulosa tinggi dan lignin yang rendah akan meningkatkan kecernaan didalam rumen (Soufizadeh et al., 2018). Kandungan lignin yang tinggi dari pakan akan menurunkan kecernaan pakan didalam rumen. Kandungan serat kasar yang rendah menyebabkan nilai kecernaan lebih tinggi (Wajizah et al., 2015).

Tabel 3. Rerata kecernaan NDF, kecernaan ADF, dan kecernaan hemiselulosa

\begin{tabular}{lccc}
\hline Pakan Hijauan Tropis & $\begin{array}{c}\text { Kecernaan NDF } \\
(\%)\end{array}$ & $\begin{array}{c}\text { Kecernaan ADF } \\
(\%)\end{array}$ & $\begin{array}{c}\text { Kecernaan } \\
\text { Hemiselulosa }(\%)\end{array}$ \\
\hline Daun Turi (DT) & $23,73 \pm 0,62^{\mathrm{d}}$ & $13,84 \pm 2,40^{\mathrm{d}}$ & $9,89 \pm 2,27^{\mathrm{ab}}$ \\
Daun Nangka (DN) & $54,78 \pm 0,71^{\mathrm{b}}$ & $27,42 \pm 2,15^{\mathrm{bc}}$ & $16,69 \pm 5,99^{\mathrm{ab}}$ \\
Daun pisang (DP) & $32,00 \pm 4,76^{\mathrm{cd}}$ & $29,06 \pm 11,74^{\mathrm{b}}$ & $2,94 \pm 7,01^{\mathrm{c}}$ \\
Daun Mangga (DMa) & $34,13 \pm 5,88^{\mathrm{c}}$ & $21,19 \pm 4,04^{\mathrm{bc}}$ & $17,80 \pm 0,46^{\mathrm{a}}$ \\
Daun Gamal (DG) & $62,29 \pm 4,99^{\mathrm{ab}}$ & $58,91 \pm 10,38^{\mathrm{a}}$ & $3,37 \pm 12,63^{\mathrm{c}}$ \\
Daun Mahoni (DMo) & $33,36 \pm 7,02^{\mathrm{c}}$ & $17,35 \pm 2,76^{\mathrm{cd}}$ & $16,01 \pm 8,91^{\mathrm{ab}}$ \\
Daun Kaliandra (DK) & $66,26 \pm 2,03^{\mathrm{a}}$ & $48,08 \pm 5,28^{\mathrm{a}}$ & $18,18 \pm 6,11^{\mathrm{a}}$ \\
Daun Lamtoro (DL) & $70,34 \pm 7,19^{\mathrm{a}}$ & $53,79 \pm 1,82^{\mathrm{a}}$ & $16,55 \pm 7,48^{\mathrm{ab}}$ \\
\hline
\end{tabular}

Keterangan: ${ }^{\mathrm{a}-\mathrm{d}}$ Superskrip berbeda pada kolom yang sama menunjukkan berbeda nyata $(\mathrm{P}<0,05)$. 


\section{Kecernaan ADF}

Kecernaan acids detergent fiber (ADF) merupakan akumulasi dari nilai kecernaan yang didalam mengandung selulosa, hemiselulosa, dan lignin. Analisis ragam menunjukkan bahwa perlakuan pakan hijauan tropis berbeda nyata $(\mathrm{P}<0,05)$ terhadap kecernaan ADF. Kecernaan ADF yang berbeda dipengaruhi oleh kadar selulosa yang tinggi dan kandungan lignin pakan yang rendah. Uji lanjut Duncan menunjukkan bahwa perlakuan lamtoro (Leucaena leucocephala), kaliandra (Calliandra calothyrsus), dan gamal (Gliricidia sepium) berbeda nyata dengan perlakuan pakan pisang (Musa acuminata), nangka (Artocarpus heterophyllus), mangga (Mangifera indica L.), mahoni (Swietenia mahagoni (L.) Jacq.), dan turi (Sesbania grandiflora). Perbedaan kecernaan ADF pakan tersebut dipengaruhi kandungan nutrien yang berbeda. Kadar lignin yang rendah pada pakan lamtoro, kaliandara, dan gamal menyebabkan pakan mudah dicerna dalam rumen. Begitupula dengan kadar selulosa tinggi sehingga peluang besar bagi bakteri rumen dalam mencerna pakan tersebut secara efektif. Lignin terdiri dari jaringan polimer fenolik yang berguna untuk merekatkan selulosa dan hemiselulosa sehingga menjadi sangat kuat. Tingkat lignifikasi yang tinggi menyebabkan pakan semakin sulit didegradasi oleh mikroba rumen.

\section{Kecernaan Hemiselulosa}

Kecernaan hemiselulosa merupakan nilai kecernaan dari pengurangan persentasi kecernaan NDF dengan kecernaan ADF. Analisis ragam menunjukkan bahwa perlakuan pakan hijauan tropis berbeda nyata $(\mathrm{P}<0,05)$ terhadap kecernaan hemiselulosa. Kecernaan hemiselulosa yang berbeda dipengaruhi oleh kadar NDF dan ADF yang berbeda.

Uji lanjut Duncan menunjukkan bahwa perlakuan pakan kaliandra (Calliandra calothyrsus) dan mangga (Mangifera indica L.) berbeda nyata dengan perlakuan pakan lamtoro (Leucaena leucocephala), mahoni (Swietenia mahagoni (L.) Jacq.), turi (Sesbania grandiflora), nangka (Artocarpus heterophyllus), gamal (Gliricidia sepium) dan pisang (Musa acuminata). Perbedaan antar perlakuan pakan diperngaruhi oleh kadar NDF dan ADF yang berbeda. Kadar NDF dan ADF pada pakan lamtoro, kaliandra, gamal maupun mangga tinggi, sehingga kecernaan hemiselulosa yang dihasilkan juga lebih tinggi dibandingkan pakan yang lainnya. Faktor lain juga dipengaruhi oleh kadar lignin dari pakan tersebut yang cukup rendah, sehingga mendukung kecernaan dalam rumen sacara efektif. Lignin dalam dinding sel tanaman mengikat selulosa dan hemiselulosa. Kadar lignin yang tinggi akan menyebabkan kecernaan rendah, sedangkan kadar lignin yang rendah menyebabkan kecernaan tinggi. Keberadaan lignin dan senyawa anti nutrisi dalam pakan akan menjadi penghambat bagi mikroba rumen untuk mencerna pakan (Badariana et al., 2014). Lignin yang ada dalam dinding sel tanaman menjadi faktor pembatas bagi proses kecernaan ternak ruminansia (Van Soest, 1994). Lignin yang ada dalam pakan menyebabkan rendahnya nilai degradasi atau fermentasi pakan dalam rumen, karena serat kasar berupa selulosa dan hemiselulosa berikatan dengan lignin dan akan sulit dipecah oleh enzim pencernan (Tillman et al., 1991).

\section{KESIMPULAN}

Hijauan pakan tropis lamtoro (Leucaena leucocephala), kaliandra (Calliandra calothyrsus), dan gamal (Gliricidia sepium) mempunyai kecernaan NDF tertinggi (70,34 \%; $66,26 \%$ dan 62,29 \%), dan kecernaan ADF tertinggi $(53,79 \%$; 48,08 \%; dan 58,91\%), namun kecernaan hemiselulosa tertinggi adalah kaliandra, mangga, dan lamtoro $(18,18 \% ; 17,80$ $\%$ dan $16,55 \%$ ). Pakan hijauan tropis lamtroro, kaliandra, gamal berpotensi sebagai pakan ternak kambing yang unggul.

\section{DAFTAR PUSTAKA}

AOAC. 1990. Official Methods of Analysis of the Association of Analytical Chemist. 15th ed. Association of Official Analytical Chemist. Arlington. VA. USA.

Ahmed, M.A., S. Jusoh, A.R. Alimon, M. Ebrahimi, \& A.A. Samsudin. 2018. Nutritive and antinutritive evaluation of Kleinhovia hospita, Leucaena leucocephala and Gliricidia sepium with respect to their effects on in vitro rumen fermentation and gas production. Tropical Animal Science Journal 41(2):128-136. DOI: https://doi.org/10.5398/tasj.2018. 41.2.128.

Badarina, I., D. Evvyernie, T. Toharmat, \& E.N. Herliyana. 2014. Fermentabilitas rumen dan kecernaan in vitro ransum yang disuplementasi kulit buah kopi produk fermentasi jamur Pleurotus ostreatus. J. Sains Peternakan Indonesia 9(2):103-109. 
Hadi, R.H., Kustantinah, \& H. Hartadi. 2011. Kecernaan in sacco hijauan leguminosa dan hijauan non-leguminosa dalam rumen sapi peranakan ongole. Buletin Peternakan 35(2):79-85.

Hartadi, H., S. Reksohadiprojo, \& A.D. Tillman. 2017. Tabel Komposisi Pakan untuk Indonesia. Edisi Keenam, Gadjah Mada University Press. Yogyakarta.

Hernaman, I., B. Ayuningsih, D. Ramdani, \& R.Z. Al Islami. 2017. Pengaruh perendaman dengan filtrat abu jerami padi (FAJP) terhadap lignin dan serat kasar tongkol jagung. Agripet 17(2): 139-143.

Hambakodu, M., \& Y.T. Ina. 2019. Evaluasi bahan pakan hasil samping agro industri terhadap kecernaan bahan kering, bahan organik dan TDN secara in vitro. Agripet 19(1):7-12. DOI: https://doi.org/10.17969/agripet. v19i1.12953

Hambakodu, M., E. Pangestu, \& J. Achmadi. 2019. Substitusi rumput gajah dengan rumput laut coklat (Sargassum polycystum) terhadap produk metabolisme rumen dan kecernaan nutrien secara in vitro. Jurnal Ilmu-Ilmu Peternakan 29(1):37-45. DOI: https://doi.org/ 10.21776/ub.jiip.2019.029.01.05.

Ikhwanti, A., I.G. Permana, Y. Retnan, A.A. Samsudin, \& A. Jayanegara. 2018. In vitro gas production of legume Bauhinia purpurea, Cassia alata, and Macroptilium atropurpureum. $3^{\text {rd }}$ Annual Applied Science and Engineering Conference, (pp: 1-5), IOP Conf. Series: Materials Science and Engineering, https://doi.org/doi:10.1088/ 1757-899X/434/1/ 012118.

Jayanegara, A., R.P. Harahap, M. Ridla, E.B. Laconi, \& Nahrowi. 2018. Chemical composition and methane emission of some tropical forage legumes from Indonesia. In AIP Conference Proceedings (Vol. 2021, No. 1, p. 050002). AIP Publishing.

Marhaeniyanto, E. \& S. Susanti. 2018. Fermentabilitas ruminal secara in vitro suplementasi tepung daun gamal, kelor, randu, dan sengon dalam konsentrat hijau. Jurnal Ilmu-Ilmu Peternakan 28 (3):213-223. DOI: https:// doi.org/ 10.21776/ub.jiip.2018.028.03. 04 .

Riswandi, L. Priyanto, A. Imsya, \& M. Nopiyanti. 2017. Kecernaan in vitro ransum berbasis rumput kumpai (Hymenachne acutigluma) fermentasi disuplementasi legum berbeda. Jurnal Veteriner 18(2):303-311. DOI: https://doi.org/10.19087/jveteriner.2017.18.2. 303.

Soufizadeh, M., R. Pirmohammadi, Y. Alijoo, \& H.K. Behroozyar. 2018. Indigestible neutral detergent fibers: Relationship between forage fragility and neutral detergent fibers digestibility in total mixed ration and some feedstuffs in dairy cattle. Veterinary Research Forum 9 (1):49-57.

Tilley, J. M. A. and R. A. Terry. 1963. A two stage technique for the in vitro. Digestion of Crops. British Grassl J. British Grassland Society 18: 104-111.

Tillman, A.D., H. Hartadi, S. Reksohadiprojo, \& S. Lebdosoekoj. 1991. Ilmu Makanan Ternak Umum. Cetakan kedua peternakan. Gadjah Mada University Press. Yogyakarta.

Van Soest, P. J. 1977. Plant fiber and its role in herbivora nutrition. The Cornell Veterinarian, 67(3): 307-326.

Van Soest, P.J. 1994. Nutritional Ecology Of The Ruminant. 2nd Ed., Comstock Publishing Associates, Cornell University Press. London.

Wajizah, S., Samadi, Y. Usman, \& E. Mariana. 2015. Evaluasi nilai nutrisi dan kecernaan in vitro pelepah kelapa sawit (oil palm fronds) yang difermentasi menggunakan Aspergillus niger dengan penambahan sumber karbohidrat yang berbeda. Agripet 15(1):13-19. 